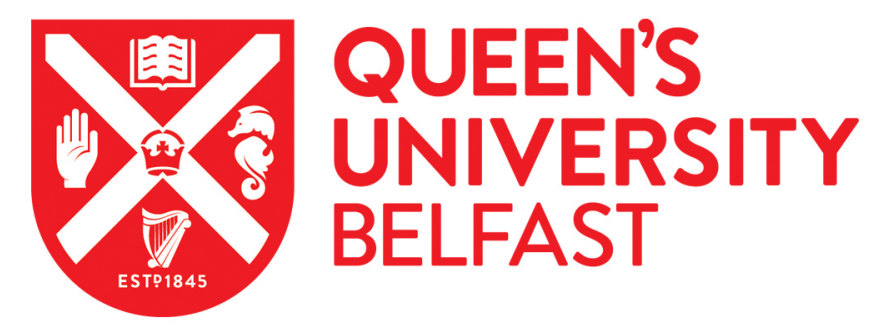

\title{
Lipogenic Potency of Individual Perfluorinated Alkyl Acids (PFAAs) and Persistent Organic Pollutant (POP) Mixtures at Human Blood- Based Exposure Levels on Adipogenesis in 3T3-L1 Cells
}

Xie, Y., Berntsen, H. F., Zimmer, K. E., Ropstad, E., Verhaegen, S., \& Connolly, L. (2021). Lipogenic Potency of Individual Perfluorinated Alkyl Acids (PFAAs) and Persistent Organic Pollutant (POP) Mixtures at Human BloodBased Exposure Levels on Adipogenesis in 3T3-L1 Cells. Exposure and Health. https://doi.org/10.1007/s12403021-00420-w

\section{Published in:}

Exposure and Health

\section{Document Version:}

Publisher's PDF, also known as Version of record

Queen's University Belfast - Research Portal:

Link to publication record in Queen's University Belfast Research Portal

\section{Publisher rights}

Copyright 2021 the authors.

This is an open access article published under a Creative Commons Attribution License (https://creativecommons.org/licenses/by/4.0/), which permits unrestricted use, distribution and reproduction in any medium, provided the author and source are cited.

\section{General rights}

Copyright for the publications made accessible via the Queen's University Belfast Research Portal is retained by the author(s) and / or other copyright owners and it is a condition of accessing these publications that users recognise and abide by the legal requirements associated with these rights.

Take down policy

The Research Portal is Queen's institutional repository that provides access to Queen's research output. Every effort has been made to ensure that content in the Research Portal does not infringe any person's rights, or applicable UK laws. If you discover content in the

Research Portal that you believe breaches copyright or violates any law, please contact openaccess@qub.ac.uk. 


\title{
Lipogenic Potency of Individual Perfluorinated Alkyl Acids (PFAAs) and Persistent Organic Pollutant (POP) Mixtures at Human Blood-Based Exposure Levels on Adipogenesis in 3T3-L1 Cells
}

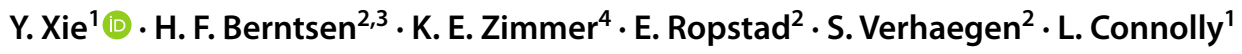

Received: 26 March 2021 / Revised: 6 July 2021 / Accepted: 27 July 2021

(C) The Author(s) 2021

\begin{abstract}
In recent decades, the incidence of metabolic disorders has increased internationally. This increase has been linked to exposure to persistent organic pollutants (POPs), but little is known about the metabolic effects of realistic human exposure mixtures at relevant concentrations. In this study we tested if POPs, representing real-life exposure profiles and concentrations, were able to disrupt development and functions of adipose tissue in a direct way. The lipogenic potency of a POP mixture modelled on levels found in human blood as detected in the Scandinavian population was assessed. The Total mixture comprises 29 compounds divided over three groups: chlorinated $(\mathrm{Cl})$, brominated $(\mathrm{Br})$ and perfluorinated compounds (PFAA). Individual PFAA chemicals, the Total mixture and sub-mixtures $(\mathrm{Cl}, \mathrm{Br}, \mathrm{PFAA}, \mathrm{Cl}+\mathrm{Br}, \mathrm{Cl}+\mathrm{PFAA}$ and $\mathrm{Br}+\mathrm{PFAA})$ at five $(\times 1 / 10, \times 1, \times 50, \times 100$ and $\times 500)$ human blood levels were tested in an optimized high content analysis (HCA) 3T3L1 adipogenesis assay. All exposures promoted adipocyte formation in 3T3-L1 cells at concentrations equivalent to $\times 1 / 10$ human blood levels. PFAAs promoted lipid accumulation in 3T3-L1 cells at $33.6 \mathrm{pM}$ (PFUnDA) and 390,460 pM (PFHxS). The Total mixture, and the $\mathrm{Cl}$, PFAA, $\mathrm{Cl}+\mathrm{Br}$ and $\mathrm{Cl}+\mathrm{PFAA}$ sub-mixtures, started to promote lipid accumulation at $\times 1 / 10$ human blood levels. This in vitro bioassay study assessed the adipogenic effects of POP mixtures modelled on real-life human exposure levels. The findings highlight that such exposures may alter adipose tissue development and function, thus potentially playing a role in the globally increasing escalation of metabolic disorders.
\end{abstract}

Keywords Persistent organic pollutants $\cdot$ Perfluorinated alkyl acids $\cdot$ Human blood relevant mixtures $\cdot$ In vitro adipogenesis $\cdot$ High content analysis

\section{Introduction}

Persistent organic pollutants (POPs) maintain a strong structural stability that enables them to persist for a long time in the environment and accumulate in biota (WHO/ UNEP 2013). Consequently, we are exposed to these chemicals and their mixtures via skin contact, our diet (including drinking water) and the air we breathe (Braun et al. 2016; Connolly 2009). Exposure to POPs has been associated with an increased risk of reproductive impairments, neurodevelopmental dysfunctions and cancers (WHO/UNEP 2013). More recently, exposure to ubiquitous chemicals has also been counted as a major contributor to the global epidemic of metabolic disruption, including health effects such as obesity, diabetes and nonalcoholic fatty liver disease and hyperlipidemia. Review of data from 1988 to 2014 shows that child growth and obesity are linked with exposures to polychlorinated biphenyls 
(PCBs), organochlorine pesticides (OCPs) and perfluorinated chemicals (Heindel et al. 2017; Karlsen et al. 2017).

As more synthetic chemicals have been introduced to our society, many have shown metabolic disrupting effects via adipose tissue. White adipose tissue is an endocrine organ which stores excessive energy in the form of triacylglycerol, a neutral lipid. This lipid is held within lipid vacuoles in adipocytes, resulting in body fat accumulation. White adipose tissue has been identified as a target of metabolic disruption by POPs (Heindel et al. 2015, Heindel and Blumberg 2019; Neel and Sargis 2011; Regnier and Sargis 2014). The investigation of POPs and their effects on adipose tissue development is necessary to help understand how environmental factors promote the pathogenesis of obesity and metabolic complications (Newbold et al. 2008). In particular, there is a need to study the metabolic disrupting effects of these chemicals at levels and mixtures representing real-life exposure. Maternal serum and breast milk levels of PCBs and organochlorine pesticides 2,2-Bis(4-chlorophenyl)-1,1-dichloroethylene dichlorodiphenyldichloroethylene ( $p, p$ '-DDE) have been linked to the subsequent development of obesity in girls (TangPéronard et al. 2014). Hence, a significant body burden of POPs in adipose tissue may lead to continuous local exposure and disruption of adipose biology. Adult studies have shown that body mass index (BMI) is inversely related to PCB blood concentrations and that weight loss can result in the release of PCBs into the circulation (Agudo et al. 2009; Dirinck et al. 2015; Hue et al. 2007). During weight loss, the breakdown and decrease of body fat can lead to the release and resulting increase in organochlorine pollutant plasma concentrations, indicating that adipose tissue can function as an in vivo exposure source of POPs (Bräuner et al. 2011; De Roos et al. 2012).

This study aimed to investigate the potential for POPs and their mixtures to disrupt adipogenesis at human relevant exposure levels, providing insight into alternative mechanisms by which POPs may be involved in the disruption of adipocyte development and pathogenesis of obesity and metabolic disorders.

To simulate real-life POP mixture exposure profiles, we utilised a synthetic mixture of 29 POPs (Table 1) which was designed on the mean human blood levels of these POPs within the Scandinavian population (Berntsen et al. 2017). These 29 POPs include three chemical groups: chlorinated chemicals $(\mathrm{Cl})$ consisting of polychlorinated biphenyls (PCBs) and OCPs, brominated chemicals $(\mathrm{Br})$ and perfluorinated compounds (PFAA). A Total mixture and 6 sub-mixtures containing the same concentration of chlorinated and brominated $(\mathrm{Cl}+\mathrm{Br})$, chlorinated and perfluorinated $(\mathrm{Cl}+\mathrm{PFAA})$, or chlorinated $(\mathrm{Cl})$, brominated $(\mathrm{Br})$, or perfluorinated (PFAA) compounds only were constructed by Berntsen et al. (2017). The sub-mixtures were created to
Table 1 Overview of the 29 different POPs constituting the Total mixture for in vitro evaluation

\begin{tabular}{llll}
\hline Chlorinated & & Brominated & Perfluorinated \\
\hline PCB & OCP & BFR & PFAAs \\
PCB 28 & $p, p^{\prime}$-DDE & PBDE 47 & PFHxS \\
PCB 52 & HCB & PBDE 99 & PFOS \\
PCB 101 & $\alpha$-Chlordane & PBDE 100 & PFOA \\
PCB 118 & Oxychlordane & PBDE 153 & PFNA \\
PCB 138 & trans-Nonachlor & PBDE 154 & PFDA \\
PCB 153 & $\alpha$-HCH & PBDE 209 & PFUnDA \\
PCB 180 & $\beta$-HCH & HBCD & \\
& $\gamma$-HCH (Lindane) & & \\
& Dieldrin & & \\
\hline
\end{tabular}

For a complete description of selection of compounds and their individual concentration, see Berntsen et al. (2017)

enable the assessment of effects upon adding or removing one or more chemical groups.

Individual PFAAs have previously been reported as biologically active in other studies assessing obesogenic potential using 3T3-L1 cells (Watkins et al. 2015). However, these effects were confirmed at higher concentrations than the human relevant levels in our mixtures. In addition, two of the compounds which are included in our mixtures, PFUnDA and PFDA, have not been previously assessed. We have also previously shown in $\mathrm{pGIP/neo} \mathrm{STC-1}$ cells that our PFAA mixture is capable of increasing secretion of glucagon-like peptide 1 (GLP-1), a gut hormone which is involved in obesity and satiety signalling pathways, more potent than the $\mathrm{Cl}$ and $\mathrm{Br}$ mixtures (Shannon et al. 2019). Consequently, we decided to also assess the adipogenic potential of the PFAA chemicals individually and at the realistic exposure levels of the human exposure study (Berntsen et al. 2017).

The 3T3-L1 murine preadipocyte cell line has previously been used to elucidate the effects of individual POPs on the development of adipose tissue (Heindel 2019; Regnier and Sargis 2014). In the current study, we aimed to utilise a 3T3L1 adipogenesis high content analysis (HCA) protocol to study the effects of real-life POP exposure on adipogenesis.

\section{Materials and Methods}

\section{Reagents}

All PBDEs, PCBs and other organochlorines were originally purchased from Chiron As (Trondheim, Norway). All PFAAs were obtained from Sigma-Aldrich (St. Louis, MO, USA) except perfluorohexanesulfonic acid (PFHxS) which was from Santa Cruz (Dallas, US). The anti-fungal reagent, hexabromocyclododecane (HBCD), phosphate-buffered 
saline (PBS) and dimethyl sulfoxide (DMSO) were obtained from Sigma-Aldrich (Dorset, UK). The nuclear stain DAPI and all cell culture reagents were supplied by Life Technologies (Paisley, UK) unless otherwise stated. The reference standard rosiglitazone (ROSI) and lipid content dye Nile Red were obtained from Premier Scientific (Belfast, UK). All other reagents were standard laboratory grade.

\section{Mixtures of Persistent Organic Pollutants (POPs)}

The POP mixtures tested in this study were designed and premade by the Norwegian University of Life Sciences, Oslo (Berntsen et al. 2017). Seven mixtures were tested in the current study: A Total mixture, containing 29 compounds, in addition to $\mathrm{Cl}, \mathrm{Br}$, PFAA, $\mathrm{Cl}+\mathrm{Br}, \mathrm{Cl}+\mathrm{PFAA}$ and $\mathrm{Br}+\mathrm{PFAA}$ sub-mixtures. Six individual PFAAs were also tested including PFHxS, perfluorooctanesulfonic acid (PFOS), perfluorooctanoic acid (PFOA), perfluorononanoic acid (PFNA), perfluorodecanoic acid (PFDA) and perfluoroundecanoic acid (PFUnDA) at concentrations equivalent to the mixture concentrations. Five concentrations of mixtures and individual compounds were used representing the widely varied human exposure scenarios, including: $\times 1 / 10, \times 1, \times 50, \times 100$ and $\times 500$ human blood relevant levels. Table 1 presents an overview of the 29 individual compounds comprising 7 mixtures and further extensive information on the mixture development can be found in Berntsen et al. (2017), whereas the concentrations of the POPs in the mixtures are available in Supplementary Table 1.

\section{Cell Culture}

The 3T3-L1 preadipocyte murine cell line (catalogue number: 86052701) capable of differentiation into mature adipocytes under hormonal stimulation was supplied by Thermo Scientific (UK). Cells were grown in $75 \mathrm{~cm}^{2}$ tissue culture flasks (Nunc, Roskilde, Denmark) at $37{ }^{\circ} \mathrm{C}$ with $5 \% \mathrm{CO}_{2}$ and $95 \%$ humidity. Culture medium containing Dulbecco's Modified Eagle Medium (DMEM), Glutamax ${ }^{\mathrm{TM}}, 10 \%$ foetal bovine serum (FBS) and 1\% penicillin and streptomycin $(50 \mathrm{U} / \mathrm{mL})$ was replaced every two days to ensure sufficient nutrient supply and anti-microbial capacity. Subculture was required when cells reached $90 \%$ confluence. Cells between passage number 7 and 17 were used for this assessment.

\section{Adipocyte Differentiation and POP Exposure}

The 3T3-L1 cells were seeded into 96-well black wall plates at 2000 cells per well in $100 \mu \mathrm{L}$ preadipocyte medium (PM (DMEM Glutamax ${ }^{\mathrm{TM}}$ supplemented with 10\% FBS and 2\% Pen/Strep)). After $48 \mathrm{~h}$, cells were exposed to treatments in differentiation medium (DM) that consisted of PM and differentiation inducing mixture (DIM) for $48 \mathrm{~h}$. The DIM consisted of $43 \mathrm{nM}$ insulin, $100 \mathrm{nM}$ dexamethasone and $25 \mu \mathrm{M}$ of 3-isobutyl-1-methylxanthine (IBMX). The solvent control (SC) containing $0.2 \%$ DMSO, positive control ROSI (at $0.4 \mu \mathrm{g} / \mathrm{mL}$ ), POP mixtures and individual PFAAs were applied to cells. All treatments were made with a final (DMSO) concentration of $0.2 \%$ in DM. After $48 \mathrm{~h}$ exposure with treatments containing DM, the wells were emptied and $200 \mu \mathrm{L}$ of insulin medium (IM) (PM with $43 \mathrm{nM}$ insulin) was added and plates were incubated for $48 \mathrm{~h}$ on Day 5 . On Day 7, the IM was replaced by PM and the plates were read $48 \mathrm{~h}$ later on Day 9. A preadipocyte control group was included where cells were maintained in PM without differentiation induction for 8 days. The protocol is shown in Fig. 1.

\section{MTT Assessment}

Metabolic activity is essential for cellular proliferation, differentiation and lipid metabolism. The metabolic activity of 3T3-L1 cells exposed to the six individual PFAAs, Total mixture, $\mathrm{Cl}, \mathrm{Br}, \mathrm{Cl}+\mathrm{Br}, \mathrm{Cl}+\mathrm{PFAA}$ and PFAA $+\mathrm{Br}$ mixtures was assessed by thiazolyl blue tetrazolium bromide (MTT) assay on Day 5 (immediately after $48 \mathrm{~h}$ exposure) and Day 9 after full adipogenic development. The test on Day 5 aims to assess the immediate effects of POP exposure on metabolic activity of 3T3-L1 cells. Apoptotic and necrotic cells lose the capacity to reduce MTT to formazan. Thus, the immediate assessment of MTT levels can examine whether POP exposure induced any cellular damage. On Day 9, the MTT readout was assessed to measure the metabolic activity of exposed and fully differentiated cells. Exposed cells were

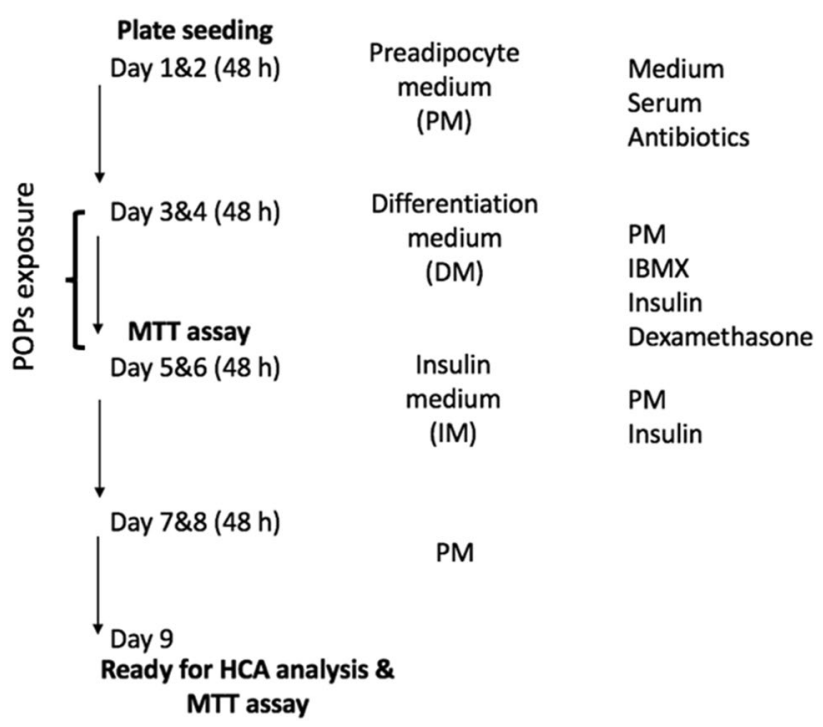

Fig. 1 Adipogenesis protocol. The adipocyte differentiation protocol for cell treatment 
washed with $200 \mu \mathrm{L}$ PBS once, and $50 \mu \mathrm{l}$ MTT solution ( $2 \mathrm{mg} / \mathrm{ml}$ stock in PBS diluted 1:6 in basal media) was added into each well and incubated at $37{ }^{\circ} \mathrm{C}$ in $5 \% \mathrm{CO}_{2}$ and $95 \%$ humidity. After $4 \mathrm{~h}$, the MTT solution was discarded, and $200 \mu \mathrm{L}$ of preheated DMSO solution was added to each well and incubated at $37^{\circ} \mathrm{C}$ for $10 \mathrm{~min}$ in a plate shaker. Optical density was measured at $570 \mathrm{~nm}$ with a reference wavelength at $630 \mathrm{~nm}$. Results were presented as percentage of the solvent control, set to $100 \%$.

\section{High Content Analysis}

High content analysis is a useful tool to collect multiple markers to assess the cellular responses to exposures. By applying fluorescent dyes, nuclear markers including cell number, nuclear area, nuclear intensity and intracellular lipid content were measured in the current study. Cell number refers to numbers of nuclei, indicating cell proliferation, growth inhibition, or cell death induced by treatment. Nuclear area and intensity give further information about the cellular health status. Changes in nuclear area and intensity can indicate cells undergoing a pre-lethal phase. Increased nuclear area and decreased nuclear intensity are more commonly observed in necrotic cells, while a small nuclear area is more related to apoptosis (Doonan and Cotter 2008). However, cell reconstruction occurs during adipogenesis, which gives smaller and denser nuclei to allow lipid droplet enlargement. Thus, in the case of 3T3-L1 cell adipogenesis, decreased nuclear area and increased nuclear intensity may occur without pre-lethal effects. Formation of lipid-containing adipocytes and intracellular lipid content represents the levels of adipogenic differentiation and lipid accumulation. Differentiated 3T3-L1 cells were stained and read on Day 9. Plates were washed once with $200 \mu \mathrm{L}$
PBS and fixed with $100 \mu \mathrm{L}$ formalin (approximately $4 \%$ formaldehyde) for $10 \mathrm{~min}$ at room temperature (RT). Cells were then washed twice with $200 \mu \mathrm{L}$ PBS and stained with $100 \mu \mathrm{L}$ of $300 \mathrm{nM}$ DAPI solution for $10 \mathrm{~min}$ at RT. After DAPI staining, two further washes in PBS were performed. A $0.25 \mu \mathrm{g} / \mathrm{mL}$ Nile Red working solution was made by dilution of the $250 \mu \mathrm{g} / \mathrm{mL}$ Nile Red DMSO stock solution in PBS and was added to each well for $20 \mathrm{~min}$. The Nile Red solution was thereafter discarded and $100 \mu \mathrm{L}$ of PBS was added to the wells prior to sealing the plates with black film to protect fluorescent staining from light. The results were read using the CellInsightTM NXT High Content Screening (HCS) platform (Thermo Fisher Scientific, UK). Images were captured at $\times 10$ objective magnification and selected filters: DAPI (Ex/Em 350/461 nm) and Nile Red (Ex/Em 554/576 nm) (Fig. 2).

\section{Data Analysis}

Exposures were carried out in triplicate wells and three independent exposures were performed $(n=3)$. Data collected from the HCA platform were processed with Excel and Graphpad PRISM software version 6.0 (San Diego, CA). All values shown are expressed as mean \pm standard deviation (SD) of three independent exposures for the compounds tested. Data are expressed as a percentage of the relevant solvent control for each parameter and analysed by one-way ANOVA followed by Dunnett's procedure for multiple comparisons; the mean concentrations were tested for significant difference at the $95 \%$ confidence level. Significant effects are represented by $P \leq 0.05(*), P \leq 0.01(* *)$ and $P \leq 0.001$ $(* * *)$. Data for adipocyte formation and lipid content results were analysed by calculating the response when compared with the positive control.
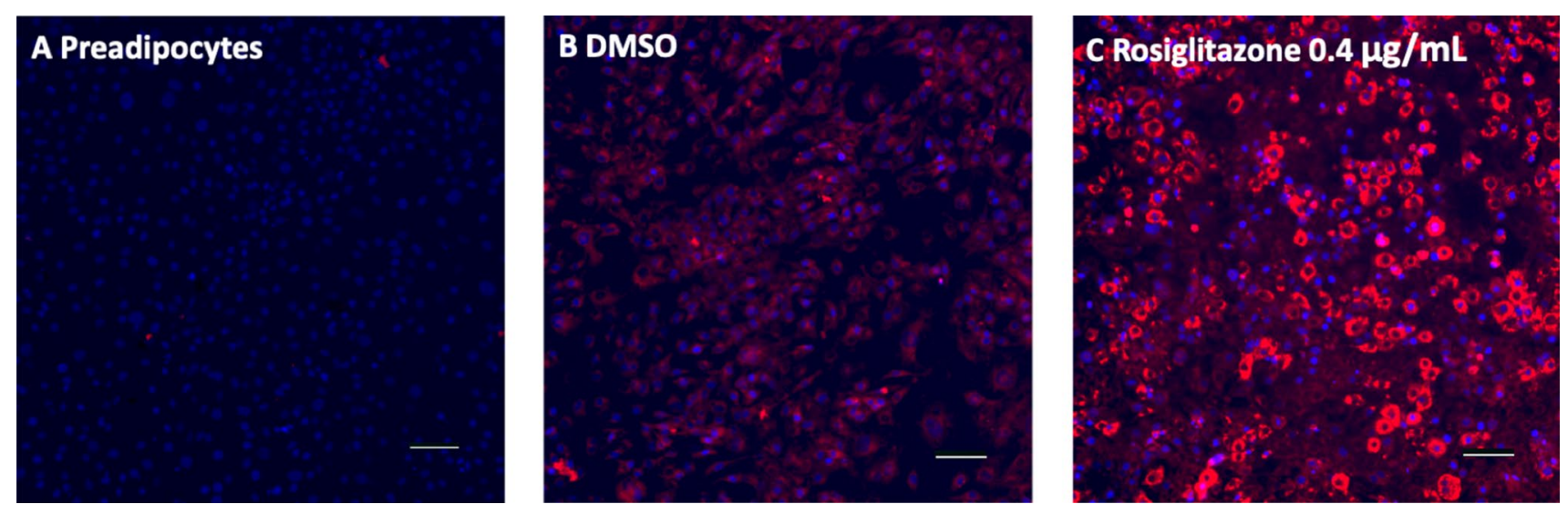

Fig. 2 High content images of fluorescent-stained 3T3-L1 cells on Day 9. A 3T3-L1 preadipocytes treated with solvent control DMSO; B 3T3-L1 cells treated with insulin, IBMX, dexamethasone, and solvent control; C 3T3-L1 cells treated with insulin, IBMX, dexametha- sone, and $0.4 \mu \mathrm{g} / \mathrm{mL}$ rosiglitazone. The typical HCA micrographs are shown with nuclei (blue, stained by Hoechst 33,342) and neutral lipid content (red, stained by Nile Red) with X 10 objective magnification, scale bars $=100 \mu \mathrm{m}$ 


\section{Results}

\section{Metabolic Activity in POP-Treated 3T3-L1 Cells by MTT}

MTT metabolic activity provides information about the cellular condition based on the levels of mitochondrial reductase activity. On Day 5, only PFHxS and PFOA significantly reduced metabolic activity (Fig. 3A). For PFHxS, this occurred from $\times 100$ blood levels and higher. For PFOA, the effect was already visible at $\times 1 / 10$ blood levels. On Day 9 only PFUnDA at $\times 500$ blood levels significantly reduced MTT activity. Numerical tabulated data are available in Supplementary Table 2.

On Day 5, the Total mixture and PFAA mixture reduced MTT metabolic activity at all tested concentrations

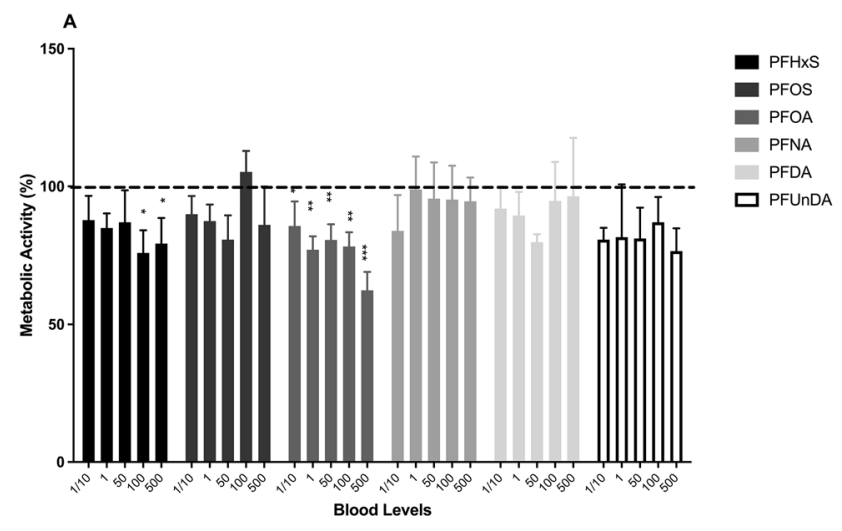

Fig. 3 MTT metabolic activity of differentiated 3T3-L1 cells after exposure to individual PFAAs. Tested after differentiation on $\mathbf{A}$ Day 5 and $\mathbf{B}$ Day 9 to individual PFAAs at $\times 1 / 10, \times 1, \times 50, \times 100$ and $\times 500$ of blood levels. Data are expressed as a percentage of sol-

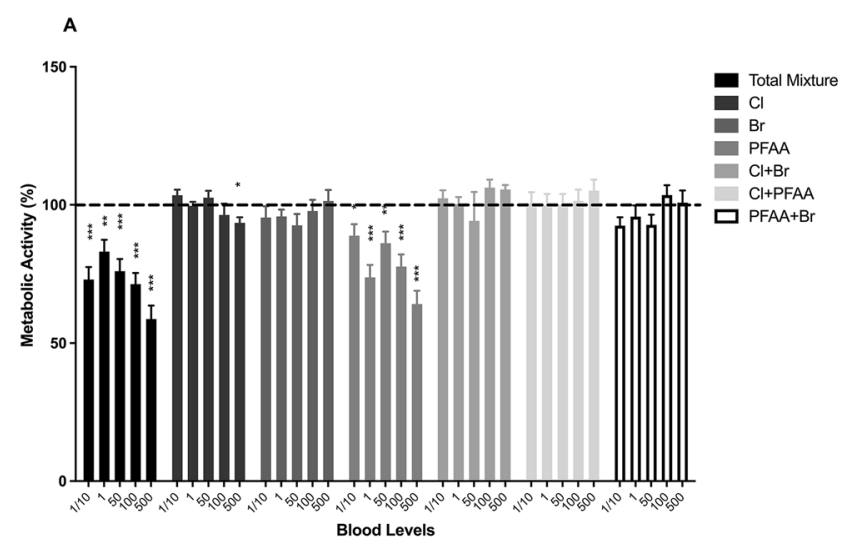

Fig. 4 MTT metabolic activity of 3T3-L1 cells after exposure to POP mixtures. Tested on A Day 5 and B Day 9, after exposure to POP mixtures at $\times 1 / 10, \times 1, \times 50, \times 100$ and $\times 500$ of blood levels. Data are expressed as a percentage of solvent control (0.2\% DMSO) set
(Fig. 4A). The $\mathrm{Cl}$ mixture decreased MTT activity at the highest concentration $(\times 500$ blood level $)$ (Fig. 4A). On Day 9, none of the POP mixtures (Fig. 4B) significantly changed the metabolic activity (Fig. 4B). Numerical tabulated data are available in Supplementary Table 3.

\section{Cell Number and Nuclear Morphology}

MTT readout revealed a decrease in metabolic activity for certain exposures. HCA nuclear markers are useful to provide additional information to explain the change of metabolic activity. Cell number was used to check for loss of cells. On day 9 , no significant changes in cell number were observed for the six individual PFAAs. Similarly, the Total mixture did not affect cell number. However, the $\mathrm{Cl}+\mathrm{Br}$ mixture led to a significant cell number reduction at $\times 50$ blood levels (Fig. 5). The $\mathrm{Cl}+$ PFAAs mixture induced a

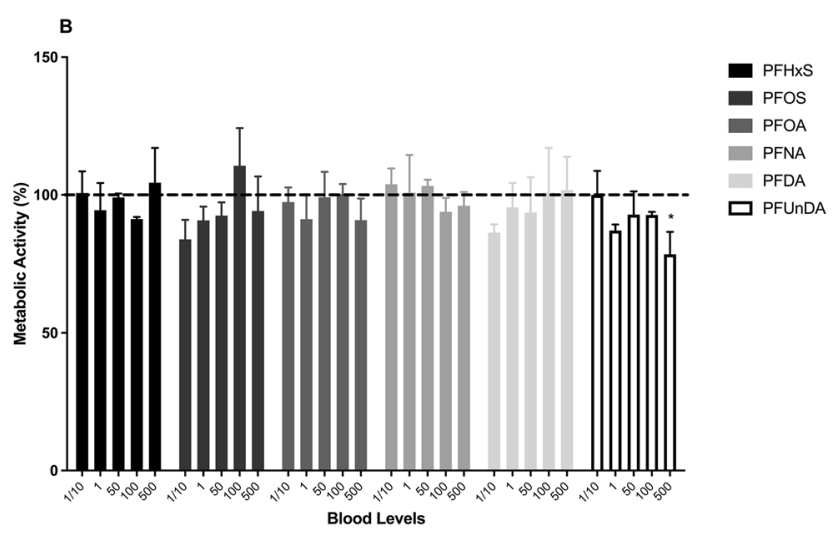

vent control (0.2\% DMSO) set at $100 \%$ (dotted line) for each parameter; mean \pm SD, $n=3 . P \leq 0.05(*), P \leq 0.01$ (**) and $P \leq 0.001$ (***) represent significant change in metabolic activity

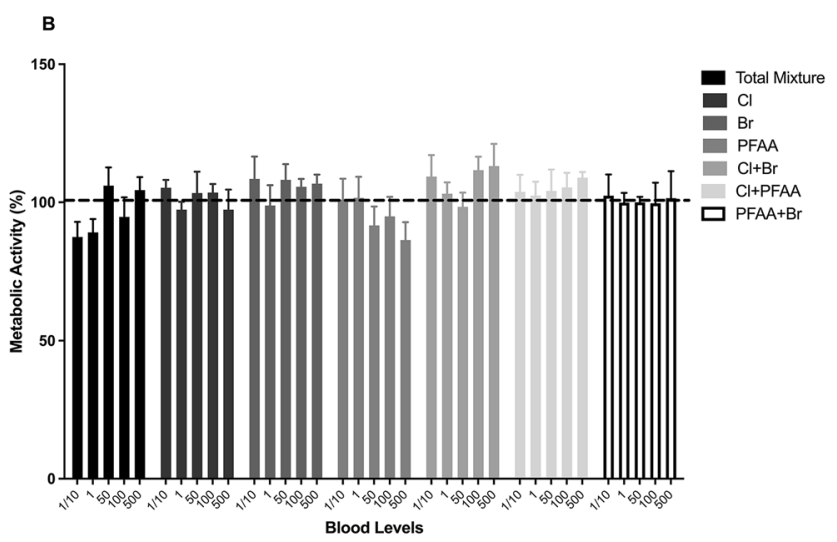

at $100 \%$ (dotted line) for each parameter; mean \pm SD, $n=3 . P \leq 0.05$ (*), $P \leq 0.01(* *)$ and $P \leq 0.001(* * *)$ represent significant change in metabolic activity 


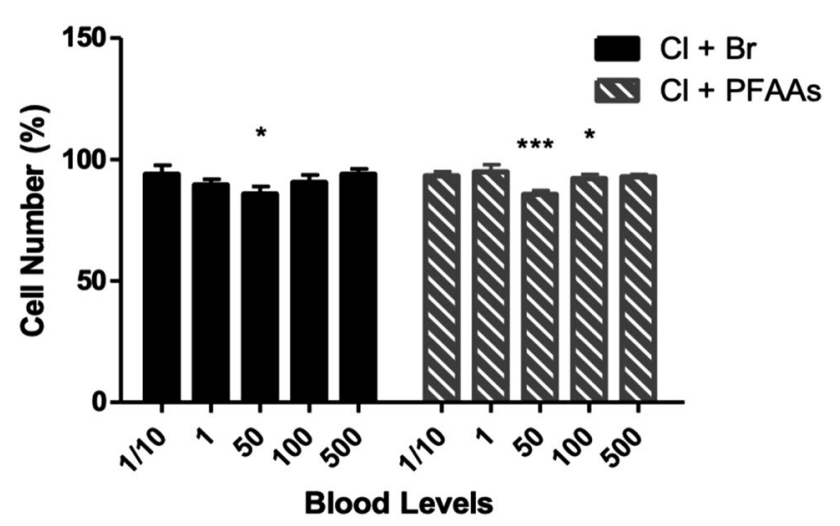

Fig. 5 Cell number of 3T3-L1 cells. Tested after differentiation on Day 9. Data are expressed as a percentage of solvent control (0.2\% DMSO) for each parameter; mean \pm SEM, $n=3 . P \leq 0.05\left(^{*}\right)$, $P \leq 0.01(* *)$ and $P \leq 0.001(* * *)$ represent significant reducing effects

significant reduction in cell number at $\times 50$ and $\times 100$ blood levels (Fig. 5).

Change in nuclear area or nuclear intensity could be indicative of cell death processes. No significant changes in these parameters were observed for any of the individual PFAAs. However, the PFAA sub-mixture induced a significant decrease in nuclear area at $\times 500$ blood levels. Neither the Total mixture, nor any of the sub-mixtures induced significant nuclear morphological change. Numerical tabulated data are available in Supplementary Tables 4 and 5.

\section{Adipocyte Formation}

The differentiated adipocytes show distinctive lipid droplet formation. The number of adipocytes in the population was calculated as a percentage of Nile red-stained cells from the Total number of cells. On Day 9, PFNA, PFDA and PFUnDA induced a significant increase in adipocyte formation at all concentrations. Both PFHxS and PFOS promoted adipocyte formation at all concentrations except $\times 100$ blood levels. PFUnDA induced the dosedependent increase in adipocytes formation, but the trend disrupted at the highest concentration (Fig. 6 and Supplementary Table 4). The Total mixture and all sub-mixtures induced significant adipocyte formation, at all tested concentrations (Fig. 7 and Supplementary Table 5).

\section{Lipid Accumulation}

The intracellular lipid accumulation present in differentiated adipocytes was assessed by measuring the intensity of fluorescent dye-stained neutral lipid content. On Day 9, PFHxS and PFNA induced significant lipid accumulation at higher concentrations $(\times 100$ and/or $\times 500)$. PFOA and PFUnDA induced significant lipid accumulation at $\times 1$ and $\times 50$ blood levels (Fig. 8 and Supplementary Table 4). The Total mixture and all the sub-mixtures, except the $\mathrm{Br}$ and PFAA $+\mathrm{Br}$, induced a significant lipid content increase at different concentrations (Supplementary Table 5). The Total, PFAA and $\mathrm{Cl}+$ PFAA mixtures presented a non-monotonic lipid content profile (Fig. 9). $\mathrm{Cl}$ mixture induced significant lipid accumulation at $\times 1 / 10$ blood level, whereas the $\mathrm{Cl}+\mathrm{Br}$ mixture promoted significant lipid increase at $\times 1 / 10, \times 1, \times 50$, and $\times 500$ blood levels.
Fig. 6 PFAAs modulate adipocyte formation during 3T3-L1 adipocyte differentiation. Percentage of adipocytes present in population following differentiation. Data are expressed as a percentage of positive control (rosiglitazone at $0.4 \mu \mathrm{g} / \mathrm{mL}$ ) for each parameter; mean $\pm \mathrm{SD}$, $n=3 . P \leq 0.05\left(^{*}\right), P \leq 0.01(* *)$ and $P \leq 0.001(* * *)$ represent significant change in adipocyte formation compared to the solvent control (set as $0 \%$ )

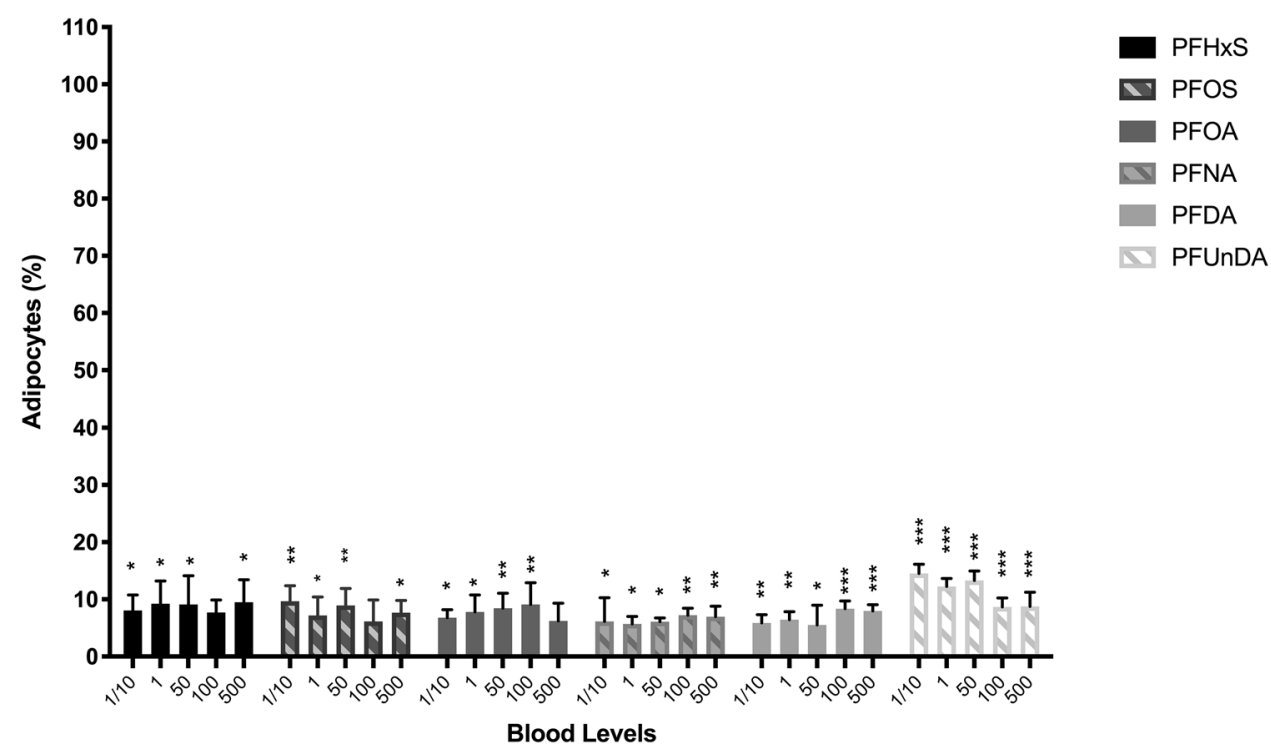




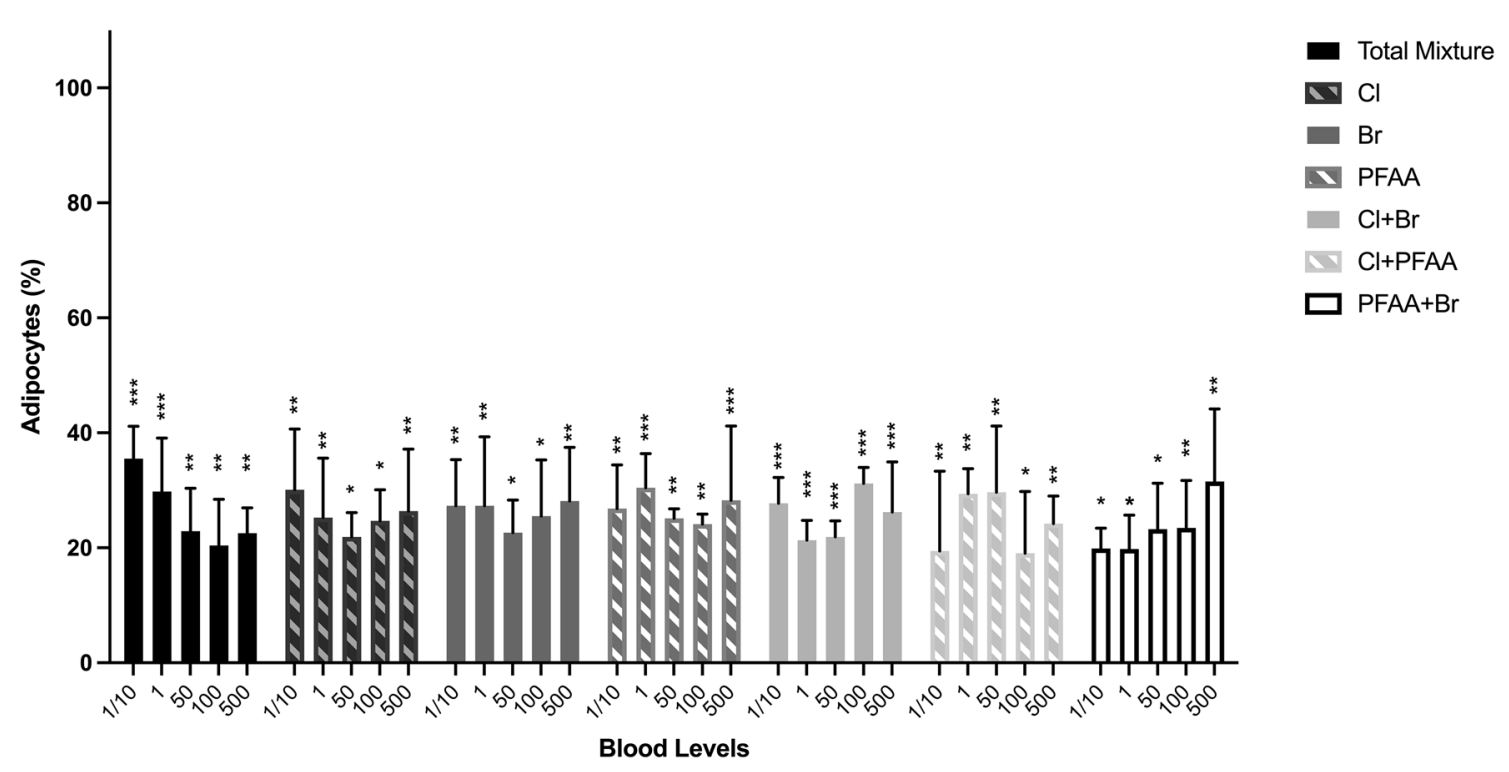

Fig. 7 POP mixtures modulate adipocyte formation during 3T3-L1 adipocyte differentiation. Percentage of adipocytes present in population following differentiation. Data are expressed as a percentage of positive control (rosiglitazone at $0.4 \mu \mathrm{g} / \mathrm{mL}$ ) for each parameter; mean $\pm \mathrm{SD}, n=3 . P \leq 0.05(*), P \leq 0.01$ (**) and $P \leq 0.001$ (***) represent significant change in adipocyte formation compared to the solvent control (set as $0 \%$ )
Fig. 8 PFAAs modulate lipid accumulation during 3T3-L1 adipocyte differentiation in a complex dose-response pattern. Increased lipid content in 3T3L1 cells after exposure to PFOS, PFHxS, PFNA and PFUnDA at $\times 1 / 10, \times 1, \times 50, \times 100$ and $\times 500$ of blood levels. Data are expressed as a percentage of positive control (rosiglitazone at $0.4 \mu \mathrm{g} / \mathrm{mL}$ ) for each parameter; mean $\pm \mathrm{SD}, n=3 . P \leq 0.05\left(^{*}\right)$, $P \leq 0.01(* *)$ and $P \leq 0.001$ $(* * *)$ represent significant change in lipid content compared to solvent control

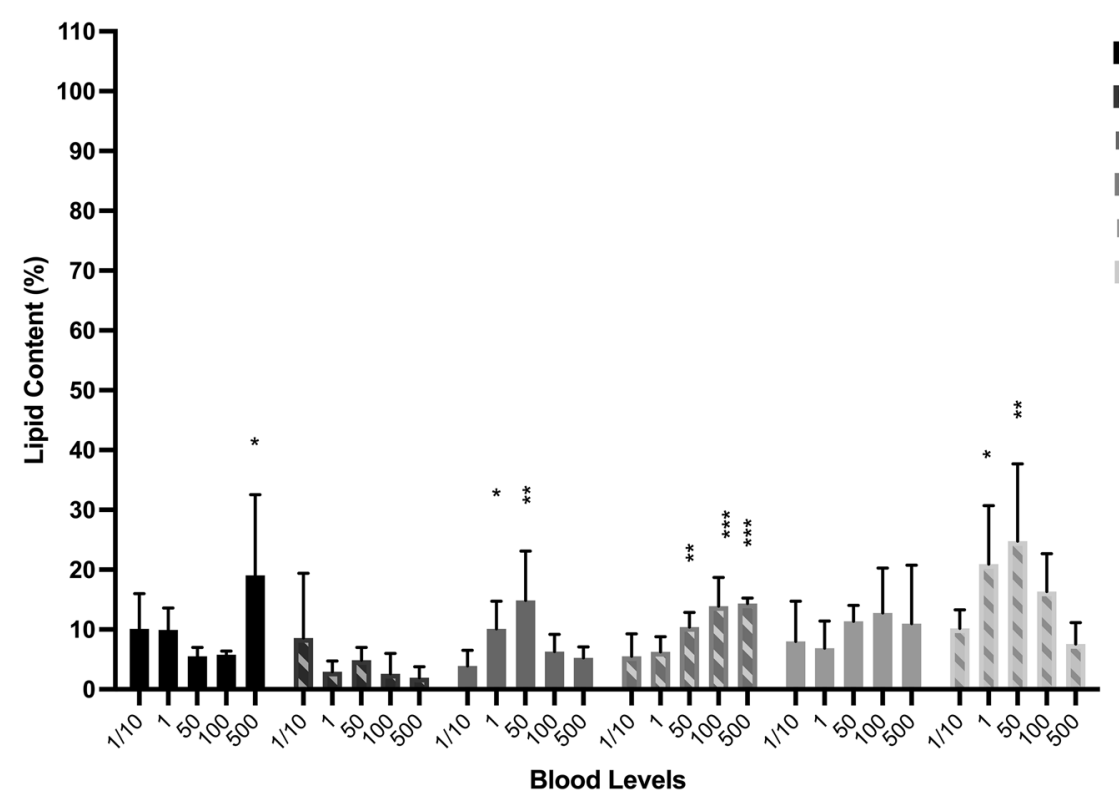

\section{Discussion}

Since the 'environmental obesogen hypothesis' announced by Grün and Blumberg (2006), extensive studies have been carried out to demonstrate the link between obesity and metabolic disorders induced by POPs (Sargis et al. 2009; Regnier and Sargis 2014; vom Saal et al. 2012; Watkins et al. 2015). In the current study, the lipogenic potential of human relevant POP mixtures and the PFAA group of chemicals that represent Scandinavian exposure concentrations has been tested. The dietary pattern and occupational environment can also lead to higher exposure levels (Fu et al. 2016; Krüger et al. 2007; Laird et al. 2013). In human and laboratory studies, the importance of low dose effects and non-monotonic dose responses have been highlighted; therefore, it is important to assess a wide range of exposures for the effective risk assessment of chemicals (Lee et al. 2010; Vandenberg et al. 2012). The blood levels of POPs in the US population have been reported as ten 


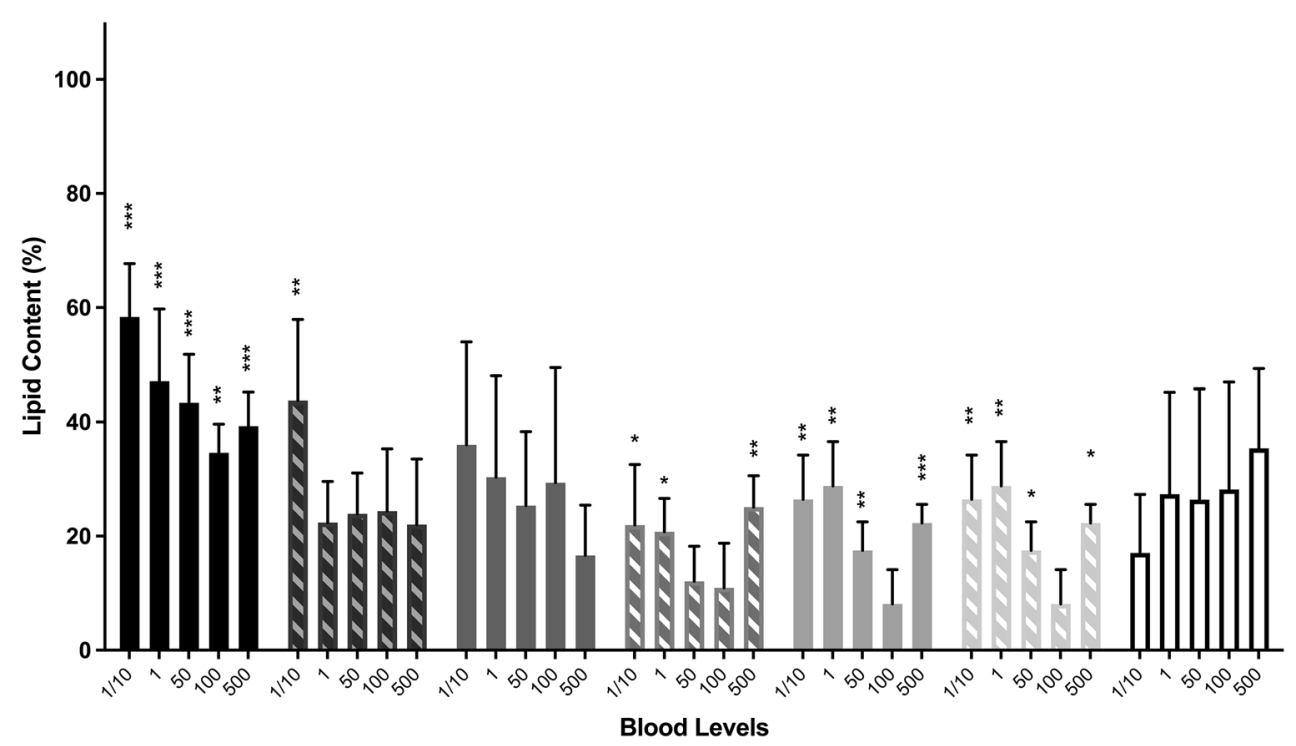

Fig. 9 POP mixtures modulate lipid accumulation in 3T3-L1 adipocyte differentiation in a complex dose-response pattern. Lipid accumulation in 3T3-L1 cells after treatment of seven POP Mixtures at $\times 1 / 10, \times 1, \times 50, \times 100$ and $\times 500$; Data are expressed as a percent- age of positive control (rosiglitazone at $0.4 \mu \mathrm{g} / \mathrm{mL}$ ) for each parameter; mean $\pm \mathrm{SD}, n=3 . P \leq 0.05\left(^{*}\right), P \leq 0.01\left(^{* *}\right)$ and $P \leq 0.001(* * *)$ represent significant change in lipid content compared to solvent control

was combined with $\mathrm{Cl}$ or $\mathrm{Br}$ chemicals, $\mathrm{Cl}+\mathrm{PFAA}$ and PFAA + Br sub-mixtures also induced less MTT change than the PFAA sub-mixture. However, the Total mixture was more potent than PFAA, which suggested that the combination of PFAA, $\mathrm{Cl}$ and $\mathrm{Br}$ chemicals together had greater effect on MTT reduction (see Supplementary Table 3).

By looking at the changes of MTT metabolic activity after differentiation on Day 9, the effects of treatments on metabolic activity and ATP production at the end of differentiation can be assessed. But here none of the pollutants (except high PFUnDA) had any effect on MTT activity. This seems to indicate that the metabolic effect of POPs, if any, is more pronounced at the start of differentiation. Between Day 5 and Day 9, cells were treated with lipogenesis-promoting and nutrient-supplying insulin medium and basal medium only. Thus, this may result in the recovery and growth of cells after withdrawal of pollutants. Enhanced mitochondrial activity during lipogenesis might also explain the restored metabolic activity at Day 9, compared to Day 5.

DAPI is a DNA binding fluorescent dye which stains nuclei, thus giving information on cell number, nuclear area and nuclear intensity (Filippi-Chiela et al. 2012). These nuclear markers were only assessed on Day 9 to investigate the cellular health condition after POP exposure and full differentiation. $\mathrm{Cl}+\mathrm{Br}$ and $\mathrm{Cl}+\mathrm{PFAA}$ mixtures induced a significant decrease in cell number. No changes in cell number were seen among all other POP exposures at any concentration. In the current study, the POP exposures failed to induce any significant changes on nuclear morphological markers in the 3T3-L1 cells, 
thus indicating absence of direct cell death induction. Combining with MTT results, the changes in cell number after exposure to the $\mathrm{Cl}+\mathrm{Br}$ and $\mathrm{Cl}+$ PFAA mixtures may impact the insulin-driven processes that downregulate clonal expansion.

By looking at cell number, nuclear area, nuclear intensity and metabolic activity, other POP exposures did not induce significant cell population changes or cellular damage in differentiated 3T3-L1 cells. However, the HCA assessment was not applied on Day 5. Thus, the current study was unable to track the changes in cell number between two end points.

The changes in adipocyte formation and lipid content of the 3T3-L1 cells were expressed as a percentage of the positive control ROSI which is a selective peroxisome proliferator-activated receptor gamma (PPAR $\gamma$ ) agonist. PPAR $\gamma$ is essential and sufficient to induce adipogenesis in vitro and embryonic adipogenesis in vivo (Chiarelli and Di Marzio, 2008; Wang et al. 2015). For relative comparison to human effects levels, the concentration of ROSI $(0.4 \mu \mathrm{g} / \mathrm{mL})$ used in this study was in the range of pharmaceutical levels (GlaxoSmithKline, 2019). Adipocyte count and lipid content are discretely separate measurements. However, the adipogenic potential of the chemicals and their mixtures tested resulted in a similar increasing trend for these two measurements.

When tested, all individual PFAAs promoted adipocyte formation, and some PFAAs showed significant intracellular lipid accumulation after adipogenic differentiation. PFHxS, PFOS and PFNA induced significant lipid content increase in 3T3-L1 cells with the lowest observed effect concentrations at 80,200 and $40 \mu \mathrm{M}$, respectively (Watkins et al. 2015). In our study, PFHxS, PFOS, PFOA, PFNA, PFDA and PFUnDA induced observable effects on adipocyte numbers at levels of 78.092, 415.221, 42.094, 10.925, 3.754 and $3.368 \mathrm{pM}$, respectively. Contradictory to previous studies (Watkins et al. 2015; Yamamoto et al. 2014), PFOA did not increase lipid content at higher concentrations $(\times 100$ and $\times 500$ blood levels). The reduction in metabolic activity on Day 5 for PFOA was observed at all tested levels. Hence the reduction in metabolic activity may be the reason of failure of lipid accumulation in the later differentiation stage at higher concentration. PFUnDA has not previously been tested in the 3T3-L1 cell line, but showed the most potent adipogenic and lipogenic property in the HCA readout. PFUnDA-induced lipid accumulation occurred at $33.68 \mathrm{pM}$, but not at the higher concentration of 3.368 and $16.84 \mathrm{nM}$. The decreased MTT activity on Day 9 observed at $16.84 \mathrm{nM}$ (corresponding to $\times 500$ blood levels) may suggest that the disrupted metabolic activity impaired the aerobic metabolism and lipid accumulation. In hPPAR $\gamma$-LBD, luciferase reporter transfected HepG2 cells, all six individual PFAAs tested in this study have been shown to activate hPPAR $\gamma$ in a dose-dependent manner (Zhang et al. 2014). Individual PFAAs mimic ROSI-promoted differentiation and lipid accumulation, indicating that these POPs could possibly act as PPAR $\gamma$ agonists.

Strikingly, several mixtures increased lipid content already at concentrations equivalent to $1 / 10$ human blood levels. The Total mixture showed the most potent lipogenic effect at this concentration. For the $\mathrm{Cl}$ mixture, this corresponds to a sum of $\mathrm{Cl}$ chemicals of $329.61 \mathrm{pM}$. Previously, individual PCBs at $1 \mu \mathrm{M}$ or combinations thereof at $1 \mu \mathrm{M}$ promoted lipid accumulation in 3T3-L1 cells (Ferrante et al. 2014). PCB 118 and 138 have been shown to promote adipogenesis of 3T3-L1 in vitro and increase adipogenesis in vivo (Kim et al. 2016a). p'p-DDE, the chlorinated compound with highest concentration in our mixture, as well as oxy-chlordane, $\gamma$-hexachlorocyclohexane $(\gamma-\mathrm{HCH})$ and dieldrin also showed adipogenic potential in adipogenesis studies (Howell and Mangum 2011; Kanayama et al. 2004; Kim et al. 2016b; Mangum et al. 2015). $\alpha$-chlordane, $\alpha-\mathrm{HCH}$ and $\beta-\mathrm{HCH}$ have not been assessed in adipose biology previously, but showed adipogenic and metabolic disrupting properties in in vivo studies (Guo et al. 2014; Lopez-Espinosa et al. 2011). HCB did not induce 3T3-L1 adipogenesis at 1, 5 and $10 \mu \mathrm{M}$ in a previous study (Bastos Sales et al. 2013). Although the $\mathrm{Cl}$ mixture did not induce a significant lipid content increase, the number of adipocytes was promoted by the $\mathrm{Cl}$ mixtures at all tested concentrations. The effects of PCBs and OCPs may interfere with adipogenesis and lipid accumulation in 3T3-L1 cells. The PFAA mixture leads to a non-monotonic response, but the highest lipid accumulation was induced already at $\times 1 / 10$ blood levels, corresponding to a concentration for the total sum of PFAA of $5.53 \mathrm{nM}$. For the $\mathrm{Cl}+\mathrm{PFAA}$ mixture, significant lipid accumulation was observed at $\times 1 / 10, \times 1, \times 50$ and $\times 500$ blood levels. A drop in lipid content occurred at $\times 50$ and $\times 100$ blood levels and accompanied a drop in cell number.

$\mathrm{The} \mathrm{Br}$ mixture promoted the formation of adipocytes, but did not induce any significant lipid accumulation at any tested concentration. BDE-47 showed significant differentiation, lipid accumulation promotion, PPAR $\gamma$ binding and expression promoting effects in 3T3-L1 cells at $3 \mathrm{nM}$ (Kamstra et al. 2014; Kassotis et al. 2017). The concentration of BDE-47 in the current study was $0.89 \mathrm{nM}$ at $\times 500$ blood levels, which is lower than the adipogenic concentration in a previous study (Kamstra et al. 2014). BDE-99, BDE-209 and HBCD did not induce any change in 3T3L1 cells up to $10 \mu \mathrm{M}$ (Kassotis et al. 2017). A mixture of BDE congeners (also containing BDE-47, 100, 153 and 209) showed adipogenesis enhancement in the 3T3-L1 adipogenesis model accompanied by PPAR $\gamma$ activation at $25.5 \mu \mathrm{M}$ (Tung et al. 2014). The sum of $\mathrm{Br}$ chemicals in our mixture was $4.905 \mathrm{nM}$ at $\times 500$ blood levels. The low concentrations of $\mathrm{Br}$ chemicals in our mixture may explain the negative results in lipid accumulation. However, rodent model studies revealed that the maternal exposure to low levels of BDE-47 
promoted obesity development with significant lipid metabolism disruption in offsprings (Gao et al. 2019; Wang et al. 2018). These in vivo results suggest that low dose exposure in early life stages may play critical roles in obesity development in later life. For PFAA $+\mathrm{Br}$, the effects on lipid accumulation are of a similar magnitude as for the PFAA or $\mathrm{Br}$ sub-mixtures alone, indicating an absence of additive effects. On the other hand, $\mathrm{Cl}+\mathrm{Br}$ mixture induced significant lipid content increase at $\times 1$ and higher blood levels, which suggested that $\mathrm{Br}$ chemicals may promote the lipogenic capacity of $\mathrm{Cl}$ chemicals.

In the current study, increased adipocyte formation and intracellular lipid accumulation after exposure to human relevant concentrations of individual PFAAs and POP mixtures were observed. Certain POP exposures impacted metabolic activity in the early stage of adipogenesis, but not the later. Although the 3T3-L1 cell model may not reflect in vivo adipogenesis and lipid metabolism, it is a useful tool to characterise potential adipogenic chemicals (Tung et al. 2014). POP-enhanced adipocyte formation and lipid accumulation may induce excessive body fat content (Grün et al. 2006). Thus, the current study findings suggest that the low dose effects of POPs on adipose tissue needs to be considered in evaluating the metabolic health effects of POPs.

\section{Conclusion}

In this study, human relevant POP mixture exposures induced significant lipid accumulation in 3T3-L1 cells. Increased adipogenesis and lipid accumulation may lead to impaired adipose tissue function and excessive fat storage in the body. Therefore, real-life POP mixture exposure at low doses may induce metabolic effects in adipose tissue. The $\mathrm{Cl}$ and PFAA sub-mixtures were the main drivers at low concentrations. Combinatorial effects were observed when $\mathrm{Cl}$ chemicals were combined with PFAAs, and $\mathrm{Cl}$ chemicals were combined with $\mathrm{Br}$ chemicals, but not in the combination of the PFAA $+\mathrm{Br}$ sub-mixture. The Total mixture induced significant adipocyte formation and lipid increases at all tested concentrations, with stronger induction than the sub-mixtures. The combinational effect suggests that compounds collectively induce effects at lower concentrations than what has previously been observed for the single compounds. This study, therefore, highlights the importance of assessing real-life exposure mixtures for effective risk assessment.

Supplementary Information The online version contains supplementary material available at https://doi.org/10.1007/s12403-021-00420-w.

Acknowledgements The POP mixtures used in this study were constructed under projects funded by the Norwegian Research Council (NFR), Project 213076/H10 and project 204361/H10.

\section{Declarations}

Conflict of interest The authors declared no potential conflicts of interest with respect to the research, authorship and/or publication of this article.

Open Access This article is licensed under a Creative Commons Attribution 4.0 International License, which permits use, sharing, adaptation, distribution and reproduction in any medium or format, as long as you give appropriate credit to the original author(s) and the source, provide a link to the Creative Commons licence, and indicate if changes were made. The images or other third party material in this article are included in the article's Creative Commons licence, unless indicated otherwise in a credit line to the material. If material is not included in the article's Creative Commons licence and your intended use is not permitted by statutory regulation or exceeds the permitted use, you will need to obtain permission directly from the copyright holder. To view a copy of this licence, visit http://creativecommons.org/licenses/by/4.0/.

\section{References}

Agudo A, Goñi F, Etxeandia A, Vives A, Millán E, López R, Amiano P, Ardanaz E, Barricarte A, Dolores Chirlaque M, Dorronsoro M, Jakszyn P, Larrañaga N, Martínez C, Navarro C, Rodríguez L, José Sánchez M, José Tormo M, González C (2009) Polychlorinated biphenyls in Spanish adults: determinants of serum concentrations. Environ Res 109(5):620-628. https://doi.org/10.1016/j. envres.2009.03.009

Bastos Sales L, Kamstra J, Cenijn P, Van Rijt L, Hamers T, Legler J (2013) Effects of endocrine disrupting chemicals on in vitro global DNA methylation and adipocyte differentiation. Toxic Vitr 27(6):1634-1643. https://doi.org/10.1016/j.tiv.2013.04.005

Berntsen H, Berg V, Thomsen C, Ropstad E, Zimmer K (2017) The design of an environmentally relevant mixture of persistent organic pollutants for use in in vivo and in vitro studies. J Toxicol Environ Health A 80(16-18):1002-1016. https://doi.org/10.1080/ 15287394.2017.1354439

Braun J, Gennings C, Hauser R, Webster T (2016) What can epidemiological studies tell us about the impact of chemical mixtures on human health? Environ Health Perspect 124(1):A6-A9. https:// doi.org/10.1289/ehp.1510569

Bräuner E, Raaschou-Nielsen O, Gaudreau E, Leblanc A, Tjønneland A, Overvad K, Sørensen M (2011) Predictors of adipose tissue concentrations of organochlorine pesticides in a general Danish population. J Eposure Sci Environ Epidemiol 22(1):52-59. https:// doi.org/10.1038/jes.2011.39

Chiarelli F, Di Marzio D (2008) Peroxisome proliferator-activated receptor-gamma; agonists and diabetes: current evidence and future perspectives. Vasc Health Risk Manage 4(2):297-304. https://doi.org/10.2147/vhrm.s993

Connolly L (2009) Endocrine disrupting chemicals: origins, fates and transmission into the food chain. In: Shaw I (ed) Endocrine disrupting chemicals in food. Elsevier, Amsterdam, pp 103-125

De Roos A, Ulrich C, Sjodin A, McTiernan A (2012) Adiposity, body composition, and weight change in relation to organochlorine pollutant plasma concentrations. J Eposure Sci Environ Epidemiol 22(6):617-624. https://doi.org/10.1038/jes.2012.43

Dirinck E, Dirtu A, Jorens P, Malarvannan G, Covaci A, Van Gaal L (2015) Pivotal role for the visceral fat compartment in the release of persistent organic pollutants during weight loss. J Clin Endocrinol Metab 100(12):4463-4471. https://doi.org/10.1210/jc. 2015-2571 
Doonan F, Cotter T (2008) Morphological assessment of apoptosis. Methods 44(3):200-204. https://doi.org/10.1016/j.ymeth.2007. 11.006

Ferrante M, Amero P, Santoro A, Monnolo A, Simeoli R, Di Guida F, Mattace Raso G, Meli R (2014) Polychlorinated biphenyls (PCB 101, PCB 153 and PCB 180) alter leptin signaling and lipid metabolism in differentiated 3T3-L1 adipocytes. Toxicol Appl Pharmacol 279(3):401-408. https://doi.org/10.1016/j.taap.2014. 06.016

Filippi-Chiela E, Oliveira M, Jurkovski B, Callegari-Jacques S, Silva V, Lenz G (2012) Nuclear morphometric analysis (NMA): screening of senescence, apoptosis and nuclear irregularities. PLoS ONE 7(8):e42522. https://doi.org/10.1371/journal.pone.0042522

Fu J, Gao Y, Cui L, Wang T, Liang Y, Qu G, Yuan B, Wang Y, Zhang A, Jiang G (2016) Occurrence, temporal trends, and half-lives of perfluoroalkyl acids (PFAAs) in occupational workers in China. Sci Rep 6:38039. https://doi.org/10.1038/srep38039

Gao H, Li P, Liu L, Yang K, Xiao B, Zhou G et al (2019) Perigestational low-dose BDE-47 exposure alters maternal serum metabolome and results in sex-specific weight gain in adult offspring. Chemosphere 233:174-182. https://doi.org/10.1016/j.chemo sphere.2019.05.277

GlaxoSmithKline (2019) AVANDIA. Gsksource.com. https://gskso urce.com/pharma/content/gsk/source/us/en/brands/avandia.html. Accessed 5 Sept 2019

Guo H, Jin Y, Cheng Y, Leaderer B, Lin S, Holford T, Qiu J, Zhang Y, Shi K, Zhu Y, Niu J, Bassig B, Xu S, Zhang B, Li Y, Hu X, Chen Q, Zheng T (2014) Prenatal exposure to organochlorine pesticides and infant birth weight in China. Chemosphere 110:1-7. https:// doi.org/10.1016/j.chemosphere.2014.02.017

Grün F, Blumberg B (2006) Environmental obesogens: organotins and endocrine disruption via nuclear receptor signaling. Endocrinology 147(6):s50-s55. https://doi.org/10.1210/en.2005-1129

Grün F, Watanabe H, Zamanian Z, Maeda L, Arima K, Cubacha R, Gardiner D, Kanno J, Iguchi T, Blumberg B (2006) Endocrinedisrupting organotin compounds are potent inducers of adipogenesis in vertebrates. Mol Endocrinol 20(9):2141-2155. https://doi. org/10.1210/me.2005-0367

Heindel J (2019) History of the obesogen field: looking back to look forward. Front Endocrinol 10. https://doi.org/10.3389/fendo.2019. 00014

Heindel J, Blumberg B (2019) Environmental obesogens: mechanisms and controversies. Annu Rev Pharmacol Toxicol 59(1):89-106. https://doi.org/10.1146/annurev-pharmtox-010818-021304

Heindel J, vom Saal F, Blumberg B, Bovolin P, Calamandrei G, Ceresini G, Cohn B, Fabbri E, Gioiosa L, Kassotis C, Legler J, La Merrill M, Rizzir L, Machtinger R, Mantovani A, Mendez M, Montanini L, Molteni L, Nagel S, Parmigiani S, Panzica G, Paterlini S, Pomatto V, Ruzzin J, Sartor G, Schug T, Street M, Suvorov A, Volpi R, Zoeller R, Palanza P (2015) Parma consensus statement on metabolic disruptors. Environ Health 14(1):54. https:// doi.org/10.1186/s12940-015-0042-7

Heindel J, Blumberg B, Cave M, Machtinger R, Mantovani A, Mendez M, Nadal A, Palanza P, Panzica G, Sargis R, Vandenberg L, vom Saal F (2017) Metabolism disrupting chemicals and metabolic disorders. Reprod Toxicol 68:3-33. https://doi.org/10.1016/j.repro tox.2016.10.001

Howell G, Mangum L (2011) Exposure to bioaccumulative organochlorine compounds alters adipogenesis, fatty acid uptake, and adipokine production in NIH3T3-L1 cells. Toxicol in Vitro 25(1):394-402. https://doi.org/10.1016/j.tiv.2010.10.015

Hue O, Marcotte J, Berrigan F, Simoneau M, Doré J, Marceau P, Marceau S, Tremblay A, Teasdale N (2007) Plasma concentration of organochlorine compounds is associated with age and not obesity. Chemosphere 67(7):1463-1467. https://doi.org/10.1016/j. chemosphere.2006.10.033
Kamstra J, Hruba E, Blumberg B, Janesick A, Mandrup S, Hamers T, Legler J (2014) Transcriptional and epigenetic mechanisms underlying enhanced in Vitro adipocyte differentiation by the brominated flame retardant BDE-47. Environ Sci Technol 48(7):4110 4119. https://doi.org/10.1021/es405524b

Kanayama T, Kobayashi N, Mamiya S, Nakanishi T, Nishikawa J (2004) Organotin compounds promote adipocyte differentiation as agonists of the peroxisome proliferator-activated receptor/retinoid X receptor pathway. Mol Pharmacol 67(3):766-774. https:// doi.org/10.1124/mol.104.008409

Karlsen M, Grandjean P, Weihe P, Steuerwald U, Oulhote Y, Valvi D (2017) Early-life exposures to persistent organic pollutants in relation to overweight in preschool children. Reprod Toxicol 68:145-153. https://doi.org/10.1016/j.reprotox.2016.08.002

Kassotis C, Hoffman K, Stapleton H (2017) Characterization of adipogenic activity of house dust extracts and semi-volatile indoor contaminants in 3T3-L1 cells. Environ Sci Technol 51(15):87358745. https://doi.org/10.1021/acs.est.7b01788

Kim H, Kwon W, Kim Y, Oh Y, Yoo S, Lee M, Bae J, Kim J, Yoo Y (2016a) Polychlorinated biphenyls exposure-induced insulin resistance is mediated by lipid droplet enlargement through Fsp27. Arch Toxicol 91(6):2353-2363. https://doi.org/10.1007/ s00204-016-1889-2

Kim J, Sun Q, Yue Y, Yoon K, Whang K, Marshall Clark J, Park Y (2016b) 4,4'-dichlorodiphenyltrichloroethane (DDT) and 4,4'-dichlorodiphenyldichloroethylene (DDE) promote adipogenesis in 3T3-L1 adipocyte cell culture. Pestic Biochem Physiol 131:40-45. https://doi.org/10.1016/j.pestbp.2016.01.005

Krüger T, Hjelmborg P, Jönsson B, Hagmar L, Giwercman A, Manicardi G, Bizzaro D, Spanò M, Rignell-Hydbom A, Pedersen H, Toft G, Bonde J, Bonefeld-Jørgensen E (2007) Xenoandrogenic activity in serum differs across european and inuit populations. Environ Health Perspect 115(Suppl 1):21-27. https://doi.org/10. 1289/ehp.9353

Laird B, Goncharov A, Chan H (2013) Body burden of metals and persistent organic pollutants among Inuit in the Canadian Arctic. Environ Int 59:33-40. https://doi.org/10.1016/j.envint.2013.05. 010

Lee D, Steffes M, Sjödin A, Jones R, Needham L, Jacobs D (2010) Low dose of some persistent organic pollutants predicts type 2 diabetes: a nested case-control study. Environ Health Perspect 118(9):1235-1242. https://doi.org/10.1289/ehp.0901480

Liu L, Shah S, Fan J, Wellen K, Rabinowitz J (2014) Quantification of NADPH balance during adipogenesis. Cancer Metab 2(S1):40. https://doi.org/10.1186/2049-3002-2-S1-P40

Lopez-Espinosa M, Murcia M, Iniguez C, Vizcaino E, Llop S, Vioque J, Grimalt J, Rebagliato M, Ballester F (2011) Prenatal exposure to organochlorine compounds and birth size. Pediatrics 128(1):e127-e134. https://doi.org/10.1542/peds.2010-1951

Mangum L, Howell G, Chambers J (2015) Exposure to p, p'-DDE enhances differentiation of 3T3-L1 preadipocytes in a model of sub-optimal differentiation. Toxicol Lett 238(2):65-71. https:// doi.org/10.1016/j.toxlet.2015.07.009

Neel B, Sargis R (2011) The paradox of progress: environmental disruption of metabolism and the diabetes epidemic. Diabetes 60(7):1838-1848. https://doi.org/10.2337/db11-0153

Newbold R, Padilla-Banks E, Jefferson W, Heindel J (2008) Effects of endocrine disruptors on obesity. Int J Androl 31(2):201-208. https://doi.org/10.1111/j.1365-2605.2007.00858.x

Regnier S, Sargis R (2014) Adipocytes under assault: environmental disruption of adipose physiology. Biochim Biophys Acta (BBA) Mol Basis Dis 1842(3):520-533. https://doi.org/10.1016/j.bbadis. 2013.05.028

Sargis R, Johnson D, Choudhury R, Brady M (2009) Environmental endocrine disruptors promote adipogenesis in the 3T3-L1 cell line 
through glucocorticoid receptor activation. Obesity 18(7):12831288. https://doi.org/10.1038/oby.2009.419

Schecter A, Päpke O, Tung K, Joseph J, Harris T, Dahlgren J (2005) Polybrominated diphenyl ether flame retardants in the U.S. population: current levels, temporal trends, and comparison with dioxins, dibenzofurans, and polychlorinated biphenyls. J Occup Environ Med 47(3):199-211. https://doi.org/10.1097/01.jom.00001 58704.27536.d2

Shannon M, Xie Y, Verhaegen S, Wilson J, Berntsen H, Zimmer K, Ropstad E, Green B, Connolly L (2019) A Human relevant defined mixture of persistent organic pollutants (POPs) affects in vitro secretion of glucagon-like peptide 1 (GLP-1), but does not affect translocation of its receptor. Toxicol Sci 172(2):359-367. https:// doi.org/10.1093/toxsci/kfz192

Tang-Péronard JL, Heitmann BL, Andersen HR, Steuerwald U, Grandjean P, Weihe P, Jensen T (2014) Association between prenatal polychlorinated biphenyl exposure and obesity development at ages 5 and $7 \mathrm{y}$ : a prospective cohort study of 656 children from the Faroe Islands. Am J Clin Nutr 99(1):5-13. https://doi.org/10. 3945/ajen.113.066720

Tung E, Boudreau A, Wade M, Atlas E (2014) Induction of adipocyte differentiation by polybrominated diphenyl ethers (PBDEs) in 3T3-L1 cells. PLoS ONE 9(4):e94583. https://doi.org/10.1371/ journal.pone.0094583

Vandenberg L, Colborn T, Hayes T, Heindel J, Jacobs D, Lee D, Shioda T, Soto A, vom Saal F, Welshons W, Zoeller R, Myers J (2012) Hormones and endocrine-disrupting chemicals: low-dose effects and nonmonotonic dose responses. Endocr Rev 33(3):378-455. https://doi.org/10.1210/er.2011-1050

vom Saal F, Nagel S, Coe B, Angle B, Taylor J (2012) The estrogenic endocrine disrupting chemical bisphenol A (BPA) and obesity. Mol Cell Endocrinol 354(1-2):74-84. https://doi.org/10.1016/j. mce.2012.01.001

Wang Q, Tao C, Jiang L, Shao M, Ye R, Zhu Y, Gordillo R, Ali A, Lian Y, Holland W, Gupta R, Scherer P (2015) Distinct regulatory mechanisms governing embryonic versus adult adipocyte maturation. Nat Cell Biol 17(9):1099-1111. https://doi.org/10.1038/ ncb3217

Wang D, Yan J, Teng M, Yan S, Zhou Z, Zhu W (2018) In utero and lactational exposure to BDE-47 promotes obesity development in mouse offspring fed a high-fat diet: impaired lipid metabolism and intestinal dysbiosis. Arch Toxicol 92(5):1847-1860. https:// doi.org/10.1007/s00204-018-2177-0

Watkins A, Wood C, Lin M, Abbott B (2015) The effects of perfluorinated chemicals on adipocyte differentiation in vitro. Mol Cell Endocrinol 400:90-101. https://doi.org/10.1016/j.mce.2014.10. 020

WHO/UNEP (2013) State of the science of endocrine disrupting chemicals-2012. World Health Organization. http://www.who.int/ceh/ publications/endocrine/en/. Accessed 1 Dec 2016

Xu X, Duan S, Yi F, Ocampo A, Liu G, Izpisua Belmonte J (2013) Mitochondrial regulation in pluripotent stem cells. Cell Metab 18(3):325-332. https://doi.org/10.1016/j.cmet.2013.06.005

Yamamoto J, Yamane T, Oishi Y, Kobayashi-Hattori K (2014) Perfluorooctanoic acid binds to peroxisome proliferator-activated receptor $\gamma$ and promotes adipocyte differentiation in 3T3-L1 adipocytes. Biosci Biotechnol Biochem 79(4):636-639. https://doi. org/10.1080/09168451.2014.991683

Zhang L, Ren X, Wan B, Guo L (2014) Structure-dependent binding and activation of perfluorinated compounds on human peroxisome proliferator-activated receptor $\gamma$. Toxicol Appl Pharmacol 279(3):275-283. https://doi.org/10.1016/j.taap.2014.06.020

Publisher's Note Springer Nature remains neutral with regard to jurisdictional claims in published maps and institutional affiliations. 